\title{
COCONUT INTERCROPPING WITH CASSAVA: AN ECONOMIC ANALYSIS
}

\author{
By \\ PRAFULLA K DAS ${ }^{1}$
}

\begin{abstract}
An evaluation of the impact of Coconut intercropping with Cassava revealed greater returns to the resource management. Contrary to the general belief, the Cassava intercrop was even beneficial to coconut, as plots with this intercrop resulted in marginally higher yields than the plots with coconut alone.
\end{abstract}

\section{Introduction}

At one time, cassava was grown extensively throughout the State of Kerala. It was, however, raised unsystematically along with several other plant species in the dense shade of crowded coconut gardens, with the result that the yields of those crops including coconuts were extremely low. Realising that such multispecies cropping systems do not pay, many farmers have resorted to the soft option of raising coconut as monocrop. But that is certainly not a right decision at least under Kerala situation where the land-man ratio is miserably low even from Indian standards. It is estimated that the average size of the operational holdings in this state is about 0.35 ha against the All India average of $1.62 \mathrm{ha}$. Such small units obviously do not provide adequate income and employment to the dependent families, when coconuts are monocropped.

In order to find out a solution to this important problem, increased attention has been given more recently to coconut-based cropping system research at the Central Plantation Crops Research Institute located in Kerala. Research findings have conclusively proved that scientifically adopted coconut-based cropping systems are capable of generating a substantially higher income and employment potential over the monocrop.

Although some of the newly designed highly complex coconut-based cropping system models were found to be the most profitable ones, they need certain critical inputs, which can not be generally met by the smallholders. For instance, since more than $90 \%$ of the 2.65 million coconut holdings in Kerala are rainfed, the vast majority of the farmers of this state will not be benefited from the hightech intensive cropping system innovations developed for irrigated land. Similarly, most of the smallholders have virtually no cash with which to operate the high investment svstems such as multistorey cropping and animal integrated mixed farming models. Borrowing of money wherever possible, at the prevailing very high rates of interest has the same effect of severely limiting operational capital. Some of the technologies, therefore, do not fit the smallholders' environment and needs. This paper highlights the merits of the coconut + cassava cropping system in Kerala context.

\section{Materials and Methods}

\section{Study Site}

Field trial on intercropping of cassava in 50 year old coconut stands was conducted at Central Plantation Crops Research Institute experimental farm, Kasaragod, during the period

\footnotetext{
${ }^{1}$ Principal Economist and Head, Division of Social Sciences, Central Plantation Crops Research Institute, Kasaragod-671 124, Kerala State, India.
} 
1973-78. The plot size was 0.10 ha. The soil type of that plot was red loam with $77 \%$ coarse sand, $3 \%$ fine sand, $2 \%$ silt and $18 \%$ clay. The palms were standing at a uniform spacing of $7.5 \mathrm{~m} \times 7.5 \mathrm{~m}$ where the density of palms comes to 175 ha. $^{-1}$ The plot was managed under the rainfed condition with a prolonged dry period spreading from December to April.

\section{Cultural Practices:}

Cassava (M4 variety) was planted in mounds in the interspaces of coconut palms at a spacing of $1 \mathrm{~m} \times 1 \mathrm{~m}$ in April-May immediately after the onset of the south-west monsoon, leaving a $2 \mathrm{~m}$ radius around the base of the coconut palms. The total number of cassava plants thus comes to $8,000 \mathrm{ha}^{-1}$. There was, a basal application of farmyard manure to the entire plot at the rate of 8 tonnes ha ${ }^{-1}$ year $^{-1}$. Besides this, both the main crop (coconut) and intercrop (cassava) were receiving the fertilizers at the recommended doses of $87 \mathrm{Kg} \mathrm{N}, 56 \mathrm{Kg}$ P205 and $210 \mathrm{Kg}$ K20 for coconuts; and $80 \mathrm{~kg}$ each of $\mathrm{N}, \mathrm{P} 205$ and $\mathrm{K} 20$ for cassava ha ${ }^{-1}$ year ${ }^{-1}$. Cassava was harvested in November-December each year.

\section{Input-Output Analysis}

Input-Output data were analysed for the purpose of impact study. The returns were worked out based on the input-output prices prevailing in Kerala during the year 1990-91, while the calorie equivalents of each of the inputs and outputs were collected from several reference books on energy.

\section{Measures of Productivity}

In monocropping, the weight of the economic yield can be taken as the Index of Productivity. In Multiple cropping, however, since several heterogeneous crops are involved, their total yield can not be taken as the Index of productivity. Because of heterogenity in the products there may not be any meaning in totalling weights of ail the products. In such a situation, we can think of aggregating the yields from different component crops into single productivity Index by giving some weights to each and every crop based on the perceived relative values of their products. Then the productivity Index $\mathrm{P}$, of a cropping pattern is computed as:

$$
\mathrm{P}=\sum_{i=1}^{n}(\text { ai } \mathrm{x} \text { i - bi) }
$$

Where ai is the assigned weight for the ith crop, xi is the yield of the ith crop, 'bi' is the given constant for the ith crop and ' $n$ ' is the total number of crops in the cropping pattern.

There are many advantages of a single productivity Index. Using this, different cropping systems can be easily compared and interpretation becomes easier. However, because of the involvement of a set of weights (ai) and constants (bi) prescribed for each and every crop, utility of this Index becomes limited. In the productivity Index, if ai's are taken as market price per unit of the ith crop and 'bi's are the costs of production (per unit) for the ith crop, then it is called as Monetory Index. This is simple to understand as it gives the total profit received by growing a particular combination of crops.

However, since the prices of agricultural crops vary too much over time and location, the use of this Index is of limited nature. If in the productivity Index ai's are the calorie values of the ith product output and bi's are the calorie values of the corresponding inputs then the Index is called as the calorie Index. This is independent of external factors; as it depends on the inherent character of the product only. In this study, both the monetary index and calorie index have been worked out. 


\section{Results and Discussion}

It is generally believed that the yields of palms are adversely affected when the intercrops are raised in coconut gardens. However, the result of the cassava intercrop trial in Kasaragod presented a different picture - the effect of intercrop on the palm yield was not unfavourable. Evidently there was some increase in the productivity of coconuts when it was being intercropped with cassava (Table 1). It was possible because of site enrichment in several ways.

Table 1. Effect of Cassava intercrop on the yield of Coconut.

\begin{tabular}{|c|c|c|c|}
\hline \multirow{2}{*}{ Treatment } & \multicolumn{2}{|c|}{ Net yield } & \multirow{2}{*}{ Percentage increase in Coconut vield } \\
\cline { 2 - 3 } & -1 Palm & $-1 \mathrm{Ha}$ & \\
\hline Coconut monocrop & 48.2 & 8,435 &, \\
Coconut + Cassava & 51.2 & 8,960 & 6.2 \\
\hline
\end{tabular}

It was however, observed that the intercrop yield (14.82 tonnes $\left.\mathrm{ha}^{-1}\right)$ under the coconut shade was far less than its average potential ( 25 tonnes $\left.\mathrm{ha}^{-1}\right)$, when cassava was cultivated with the same level of package of practices as a monocrop in open. Since cassava is basically a sun loving crop, such a performance was not unexpected under this given situation. Despite this fact, the analysis of this trial has indicated that it is possible to increase the income of the coconut garden through scientific adoption of cassava intercrop. Based on the econornic situation of 1990-91, an additional net income of Rs. $8168 \mathrm{ha}^{-1}$ year $^{-1}$ (US \$ 408)* was realised from cassava intercrop alone. The advantage of cassava intercrop is that it yields a fairly good return for very few inputs. In other words, the income from cassava even under the coconut shade is sufficient to offset its cost of production. The combined income from the coconut + cassava cropping system was therefore, found to be significantly higher than those realised solely from coconut monoculture (Table 2).

* US \$ = Rs. 20 (Rate prior to devaluation)

Table 2. Estimated Costs and Returns for the Coconut monocropping and Coconut + Cassava Cropping Systems.

\begin{tabular}{|c|c|c|c|c|c|c|}
\hline \multirow{2}{*}{ Treatment } & \multicolumn{2}{|c|}{ Gross Cost } & \multicolumn{2}{c|}{ Gross Return } & \multicolumn{2}{c|}{ Net Return } \\
\cline { 2 - 6 } & Rs Ha-1 & $\begin{array}{c}\text { \% increase } \\
\text { over monocrop }\end{array}$ & Rs Ha-1 & $\begin{array}{c}\% \text { increase over } \\
\text { monocrop }\end{array}$ & Rs Ha-1 & $\begin{array}{c}\text { \% increase } \\
\text { over monocrop }\end{array}$ \\
\hline Coconut monocrop & 16,750 &.. & 22,000 &.. & 5,250 &.. \\
Coconut + Cassava & 23,400 & 39.7 & 38,620 & 75.5 & 15,220 & 190.0 \\
\hline
\end{tabular}

Note: Market Rates in Kerala during 1990-91

The estimated IER for the coconut + cassava cropping system was found to be 1.65 suggesting that 1.65 ha of land area is required under sole cropping to produce the same gross income as that realised from 1 ha of the intercropping system at the same management level. That means, by adopting this system approach in 1 ha garden, a farmer could save 0.65 ha of land of generating a given level of income as intercropping offers an effective means of increasing the productivity of land. In a land hungry state like Kerala, the judiciously planned cropping system approach therefore, assumes greater importance. 
As we have already discussed, there are several alternative cropping system models which could generate much higher economic returns, but in a subsistence farm where the well-being of the family overrides profit considerations, the coconut + cassava cropping system seems to be quite appropriate one. It is because, cassava is adaptable to the adverse conditions of poor and light soils, moisture stress and shaded palm groves. The management of this crop is also quite simple and within the capability of the smallholder. It does not pose much problems of pests and diseases.

Though the labour requirement of coconut + cassava cropping system was of the order of 251 mandays ha- ${ }^{1}$ year- ${ }^{1}$ compared to 120 mandays in the case of coconut monocrop the productivity of labour was high enough to attract it into the production systems (Table 3). Cassava is a good calorie source and it provides an essential component of the family diet at a lower cost. As far as this study was concerned, the estimated calorie index for coconut + cassava cropping was more, than three times that of coconut sole cropping (Table 4).

Table3. Estimated Labour Requirements and Labour Productivity of Coconut monocropping and Coconut + Cassava Cropping Systems

\begin{tabular}{|c|c|c|c|c|c|}
\hline \multirow{2}{*}{ Treatment } & \multicolumn{3}{|c|}{ Labour Requirements for } & \multirow{2}{*}{$\begin{array}{l}\% \text { increase due to } \\
\text { intercropping }\end{array}$} & \multirow{2}{*}{$\begin{array}{l}\text { Return to Labour } \\
\text { (Rs.manday) }\end{array}$} \\
\hline & Coconut & Cassava & System & & \\
\hline Coconut monocrop & 120 & " & 120 & “ & 43.60 \\
\hline Coconut + Cassava & 104 & 147 & 251 & 109.2 & 60.60 \\
\hline
\end{tabular}

Table 4. Estimated Calorie Index (CI), Monetary Index (MI), Income Equivalent Ratio (IER) and Return to Investment in Coconut monocropping and Coconut + Cassava Cropping Systems.

\begin{tabular}{|c|r|r|r|c|}
\hline Treatment & $\mathrm{Cl}\left(\mathrm{Kcal} \times 10^{4}\right)$ & MI (Rs.) & \multicolumn{1}{c|}{ IER } & Return to Investment (\%) \\
\hline Coconut monocrop & 603.0 & 5,238 & 1.00 & 12.7 \\
Coconut + Cassava & $1,903.7$ & 15,218 & 1.65 & 37.0 \\
\hline
\end{tabular}

U\$ \$ 1 Rs. 20 (Rate prior to devaluation).

\section{Inputs}
Labour wage
: Rs. 28.00 per day
Urea
: Rs. 2.40 per kg.
Cassava stems (Planting material) : Rs. 250.00 per ha
Super Phosphate
: Rs. 1.00 per kg
Farmyard manure
: Rs. 100.00 per tonne. Muriate of Potash.
: Rs. 1.40 per kg
Outputs
Coconut
: Rs. 2.50 per nut
Cassava
: Rs. 1.00 per kg.
Conversion Rate:

US $\$ 1=$ Rs. 20.00 
Besides all these factors, the relevance of cassava cultivation has been strengthened much more in the present day Kerala situation where rice production has become a costly affair. Unlike rice, cassava requires a few inputs and less subject to vagaries of weather as well as marketing systems. Although shaded conditions delay this tuberizations in cassava markedly, still it is found to be advantageous to follow coconut + cassava cropping system from several accounts. The principal benefit to the coconut farmer might be in providing a relatively stable income in the face of higher uncertainities of coconut prices.

Some other research findings have indicated that cassava intercropping need not be confined to the understorey of fully grown coconut gardens alone, it could also be well adopted at the early prebearing stage of the coconut plantation. In order to assess the impact of cassava intercropping with the young coconut plants, a field experiment was carried out at Central Tuber Crops Research Institute in Trivandrum during the early eighties. Since proper spacing was followed, the system did not affect the root spread of coconut plants. At the same time, no appreciable reduction in the dry matter production of cassava was noticed, because of the adoption of the recommended package of practices for both the crops. This finding is the most encouraging aspect of the intercropping system in a perennial crop with a long pre-bearing period as in the case of coconuts, because it offers early financial returns which can serve to offset partly or fully the establishment costs of coconuts, while providing a sustained income to the small-holder when no other source of livelihood is available to him.

Eventhough cassava has a fairly long history in Kerala it is slowly losing its importance as a staple crop, because oithe better standard of living of the people in this state. But its demand could be stepped up if the alternate uses are found out. It is most unfortunate that no serious thought: has been given to the utilization of cassava as animal feed. While India in general and Kerala in particular arc facing acute shortage of high calorie feed for their bovine population which is the highest in the world, the increase in the production of this tuber crop should not pose a problem if proper post-harvest technologies are adopted to cater to the needs of the animal feed industry in this country. We can also learn from the experiences of our neighbouring countries like Thailand where cassava has become an important export crop for the pig industry of the European Economic Community markets. While this crop is receiving greater attention throughout the tropical countries in the world as an intercrop under various perennial tree crops such as coconut, cocoa and rubber, in India there should be more $\mathrm{R} \& \mathrm{D}$ efforts in making it a more compatible and profitable understorey crop in various situations.

\section{DR. P.K. DAS}

Dr. P.K. Das, who currently is the Principal Scientist and Head, Social Science of the Central Plantation Crops Research Institute, joined the institute as a scientist and later as Head of the Economics Department. After obtaining his Masters degree in Agricultural Economics in 1962, he joined the Orissa University of Agriculture and Technology as Assistant Professor in 1963. During this time he visited the U.S.A. under the USAID programme to carry out the course work under the University of Missouri, Columbia in Production Economics in 1968-69 and research work at Indian Agricultural Research Institute, New Delhi in 1970-71. He obtained his Ph.D. degree in 1972 with Gold Medal.

Following his resignation as Senior Economist from the National Dairy Research Institute in 1977, he joined the Central Plantation Crops Research Institute and his major research programmes are on the Economics of Coconut Production Technologies. Dr. Das visited Laos as an ILO consultant in 1976 and attended the APCC $27^{\text {th }}$ Cocotech meeting in Manila in 1990, as a resource speaker on the Economics of Coconut Based Farming System. He published some 65 research papers, 32 of which are on coconut economics and marketing. 